Case Report

\title{
IgG4-Related Sclerosing Disease Causing Spinal Cord Compression: The First Reported Case in Literature
}

\author{
Nooraldin Merza $\mathbb{D}^{1},{ }^{1}$ Ahmed Taha $\mathbb{D}^{1},{ }^{1}$ John Lung $\mathbb{D},^{2}$ \\ Anthony W. Benderman, ${ }^{3}$ and Stephen E. Wright ${ }^{4}$ \\ ${ }^{1}$ Department of Internal Medicine, Texas Tech University Health Sciences Center, Amarillo, TX, USA \\ ${ }^{2}$ School of Medicine, Texas Tech University Health Sciences Center, Amarillo, TX, USA \\ ${ }^{3}$ Department of Pathology, Veterans Affairs Medical Center, Amarillo, TX, USA \\ ${ }^{4}$ Department of Hematology and Oncology Medicine, Veterans Affairs Medical Center, Amarillo, TX, USA
}

Correspondence should be addressed to Nooraldin Merza; nooraldin.merza@ttuhsc.edu

Received 15 April 2019; Accepted 4 June 2019; Published 18 June 2019

Academic Editor: Christian Drouet

\begin{abstract}
Copyright (C) 2019 Nooraldin Merza et al. This is an open access article distributed under the Creative Commons Attribution License, which permits unrestricted use, distribution, and reproduction in any medium, provided the original work is properly cited.

Immunoglobulin G4-related disease (IgG4-RD) is known for forming soft tissue mass lesions that may have compressive effects. It is an extremely rare disease that most frequently affects the pancreas causing autoimmune pancreatitis. It can also affect the gallbladder, salivary glands, and lacrimal glands causing respective organ-specific complications. In our report, we describe an IgG4-RD case that affected the spinal cord. A 60-year-old female presented with cervical spinal cord compression caused by IgG4-RD leading to several neurological deficits. Pathological examination of the excisional biopsy of the mass revealed dense lymphoplasmacytic cells infiltration and stromal fibrosis with IgG4 and plasma cells. The patient showed a dramatic response to the administration of systemic steroids with almost resolution of her neurological symptoms. This case highlights the first case in literature for IgG4-RD of the extradural tissue causing spinal compression. Hereby, we also demonstrate the dramatic response of IgG4-RD to the administration of systemic steroids as the patient had no recurrence after 5 years of close follow-up, the longest reported period of follow-up reported in the literature to date.
\end{abstract}

\section{Background}

IgG4-related disease (IgG4-RD) is an extremely rare condition that can affect the pancreas, liver, salivary glands, kidneys, lungs, central nervous system (CNS), and the heart. It is diagnosed based on the clinical presentation, hematological data, and histopathological criteria. Very limited data is available about the CNS involvement in IgG4-RD because it is an extremely entity of the disease.

The manifestations of IgG4-RD when it affects the CNS depends typically on the location of the sclerotic mass. IgG4$\mathrm{RD}$ have been previously described in the literature as it affected the pituitary gland and manifested as hypophysitis [1], the meninges and manifested as intracranial hypertrophic pachymeningitis [2-4], or the brain parenchyma and presented as an inflammatory pseudotumor [5]. We, hereby, present the first case in literature to describe IgG4-RD of the spinal extradural tissue. We also demonstrate the dramatic response of the disease to the administration of systemic steroids as the patient had no recurrence after 5 years of close follow-up.

\section{Case Presentation}

A 60-year-old Caucasian female with medical history of obstructive sleep apnea, seasonal allergies, and osteoarthritis who presented with weakness and numbness in all four extremities for 4 weeks. Initially, she had bilateral burning pain at the tips of her fingers and toes that progressed later to pin-and-needle paresthesia. The paresthesia was associated with low grade fever, bowel and bladder incontinence, and vague dull neck pain. Her home medications are acetaminophen, methocarbamol, and vitamin D supplementation and she is allergic to aspirin, calcium, cortisone 


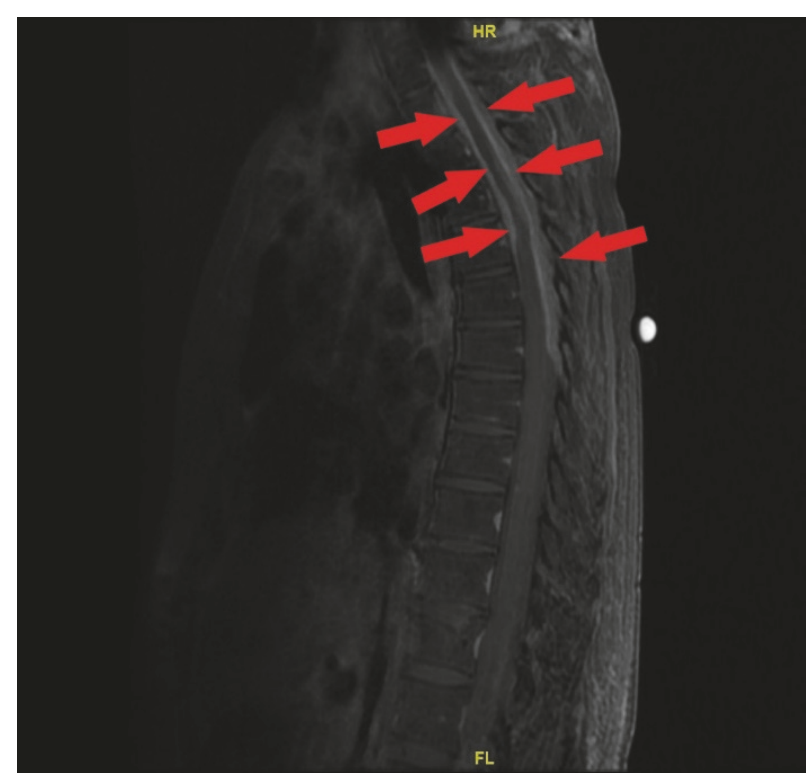

FIgURE 1: T1-weighted Thoracic spine Magnetic Resonance Imaging showing diffuse extradural mass effect and enhancement from the T1 level to the T5 level anteriorly and to the T7 level posteriorly; most prominent at the T4-T5 level where there is marked spinal canal stenosis and mass effect upon the spinal cord.

meperidine, phenytoin, gabapentin, ibuprofen, naproxen, penicillin, salicylate, and sulfa drugs. She denied alcohol, tobacco, and illicit drug use.

She has a past surgical history of 2 caesarian sections, hemorrhoidectomy 31 years ago, and splenectomy after a remote vehicle accident 35 years ago. 5 months prior to this presentation, she underwent decompressive laminectomy for a C1-C5 cervical mass originating from the dorsal part of the cervical epidural space. The pathology report from the resected mass revealed an inflammatory mass with extensive collagenized background and a polymorphous-appearing cell infiltrates with a mixture of small lymphoid cells, plasmacytoid cells, very occasional eosinophils, and neutrophils.

At admission, she was alert and oriented and maintaining normal vital signs. Physical examination revealed that her neck was supple without lymphadenopathy but was significant for neck tenderness. CNS examination revealed intact cranial nerves, $3 / 5$ power strength and $2+$ reflexes in upper extremities bilaterally, 2/5 strength and $3+$ reflexes in lower extremities bilaterally, intact sensation in all four extremities, and no saddle anesthesia. The rest of the physical examination was unremarkable.

CBC, serum electrolytes, and blood chemistry were unremarkable. Magnetic resonance imaging (MRI) of the thoracic spine showed T2-diffuse enhancement of extradural soft tissue mass with marked spinal canal stenosis, most prominent at the level of T4-T5 (Figure 1). Whole body positron emission tomography (PET) scan showed no evidence of malignancy with no abnormality demonstrated in the spleen, liver, pancreas, salivary or adrenal glands. There were prominent bilateral jugular nodes with a standard uptake value of 2.6 on the right and 2.3 on the left. Lumbar puncture was performed and cerebrospinal fluid (CSF) cytological analysis revealed mature lymphocytes and monocytes with no malignant cells.
Flow cytometry showed no immunophenotypic evidence of non-Hodgkin's lymphoma.

A laminectomy of T2 through T6 with excisional biopsy of the epidural mass was performed. The histological examination of the extradural mass chronic inflammatory infiltration composed of lymphocytes, plasma cells, histiocytes, neutrophils, eosinophils, mast cells (Figure 2(a)). It also showed dense collagen deposition and fibrous tissue formation with focal germinal center formation (Figure 2(b)). The classic storiform fibrosis pattern was identified in the biopsy material, but no phlebitis obliterans was identified. KAPPA-ISH and lambda-ISH stains showed poly-clonality with an equal mixture of kappa positive and lambda positive plasma cells. AFB and PAS stains show no mycobacterial or fungal organisms. Immunohistochemistry was performed to evaluate the nature of the plasma cells, and it revealed an IgG4+/IgG+ ratio of $47 \%$ which was diagnostic for IgG4-RD. Serum immunoglobulins were then checked and showed a total IgG of $17.65 \mathrm{~g} / \mathrm{L}$ and elevated IgG4 fragment $(2.07 \mathrm{~g} / \mathrm{L})$.

\section{Treatment/Follow Up}

After the surgery, the patient was discharged to an acute rehabilitation facility and then home but she continued to have quadriparesis, bowel and bladder incontinence, and limited ambulation due to motor weakness and poor sensation. It was almost 6 weeks until the final pathology report was received that confirmed the diagnosis of IgG4-RD, after which she was started on weekly pulse doses of oral dexamethasone $40 \mathrm{mg}$ split into 4 doses. Due to her corticosteroid allergy, she was pretreated with $50 \mathrm{mg}$ diphenhydramine 30 minutes before the administration of dexamethasone.

A dramatic clinical improvement was achieved, particularly in her quadriparesis, after the administration of systemic 


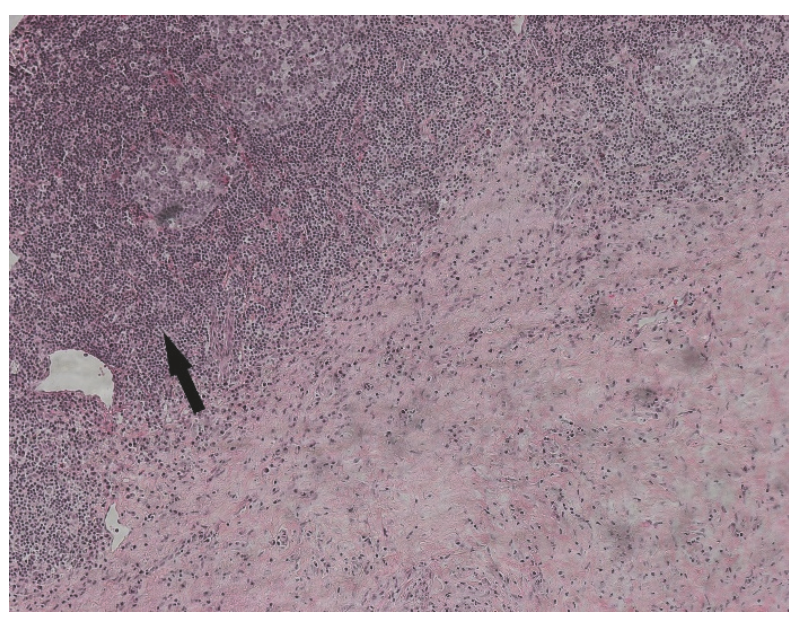

(a)

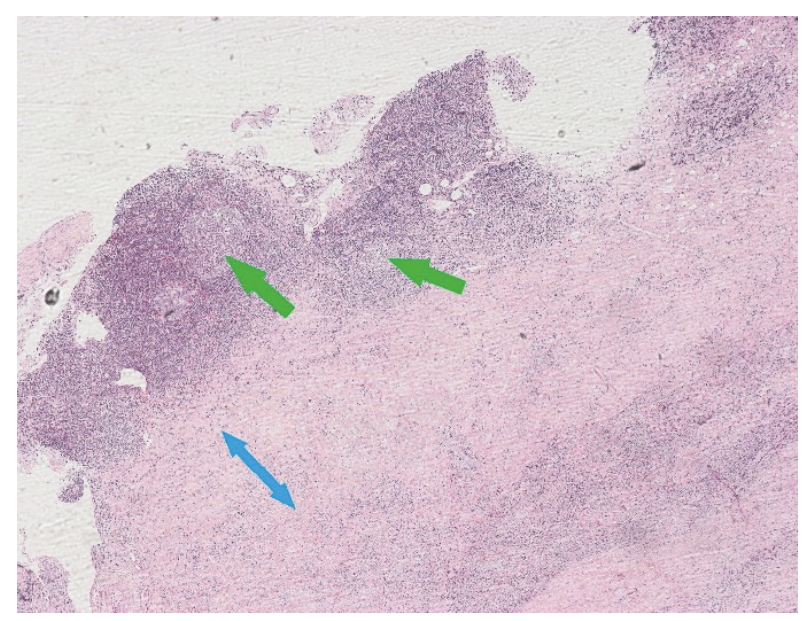

(b)

Figure 2: Hematoxylin and Eosin (H\&E) section of the epidural mass (200x magnification power for (a) and 100x magnification power for (b)) showing (a) chronic inflammatory infiltrates, predominantly mononuclear infiltrate, lymphoid hyperplasia (black arrow) and plasma cells emulating the classic storiform fibrosis pattern; no phlebitis obliterans were identified. (b) Dense collagen deposition and dense fibrous tissue formation (blue arrow) with focal germinal center formation (green arrows).

corticosteroids. She was able to walk with walker within 34 months, then independently in about a year. Her hand Fine motor skills have improved tremendously and she is currently able to perform knitting. Her bowel and bladder dysfunction also recovered completely. Over the course of 5 years of close follow up, she was kept on dexamethasone $40 \mathrm{mg}$ weekly preceded with diphenhydramine and she did not experience any disease relapse. Annual follow-up MRI images have shown no disease recurrence and IgG levels remained suppressed for 5 years after the initial diagnosis and treatment, the longest follow-up period for IgG4-RD reported. Serum IgG4 levels in relation to her compliance to Dexamethasone is outlined in Figure 3.

\section{Discussion}

IgG4-RD is a rare disease which was first recognized as one of the causes of autoimmune and sclerosing cholangitis [6]. Subsequently, extra-pancreatic organ involvement was reported, these include the liver (e.g., sclerosing cholangitis when involving intrahepatic ducts), salivary glands (e.g., IgG4-sialadenitis and its variants), kidneys (e.g., interstitial nephritis), lungs, and rarely the CNS or cardiac tissue [1]. The diagnosis is so challenging, and in most cases, it ends up reported as an idiopathic inflammatory disorder. IgG4-RD can also affect several organ systems making the differential diagnosis list too lengthy.

The diagnosis of IgG4-RD relies on clinical, hematologic, and histopathologic criteria. These include patients' presentation with characteristic diffuse or localized masses in single or multiple organs, elevated serum IgG4 levels $>1.35 \mathrm{~g} / \mathrm{L}$, marked fibrosis with lymphocytic and plasmacytic infiltration with positive immunohistochemical staining for IgG4 on histological examination. IgG4+/IgG ratio $>40 \%$ and $>50$ IgG4+ plasma cells/high power field are also very suggestive for IgG4-RD on pathological examination [7].
The immunological mechanism of IgG4-related sclerosing disease is not completely understood. The prevailing theory is the one that involves molecular mimicry based on an immune response to self-antigens that results in an increased regulatory T-cell and type 2 T-helper (TH2) cell response that results in persistent inflammation [8]. IgG4 antibodies bind to the epithelial lining of various organs and react with autoantigens causing the chronic inflammatory reaction required to develop IgG4-RD [6]. However, the role of IgG4 in the pathogenesis is unclear, though higher levels of IgG4 clearly correlate with disease severity [9].

IgG4-RD has been reported to affect the CNS in literature. The most common CNS manifestation of IgG4$\mathrm{RD}$ is hypertrophic pachymeningitis where it lead to dural hypertrophy (and thickening) which will eventually lead to symptoms such as headaches, cranial nerve dysfunctions, sensory and/or motor symptoms depending to the location, either intracranially or spinally [3]. Meningeal involvement of IgG4-RD might be confused with many differential diagnoses including; Idiopathic hypertrophic pachymeningitis, inflammatory myofibroblastic tumor, lymphoma, granulomatosis with polyangiitis, giant-cell arteritis, Langerhans-cell histiocytosis, and sarcoidosis [10].

17 cases were reported in the literature where IgG4-RD hypertrophic pachymeningitis (Table 1) was causing nerve compression symptoms lasting for months [11-13]. Our case report is the first case in literature where IgG4-RD caused an extradural mass complicated by spinal cord compression.

Unlike other systemic inflammatory diseases such as sarcoidosis or systemic scleroderma, the immunological manifestations of IgG4-RD are reversible with corticosteroids. Once the diagnosis has been made, the disease often dramatically responds to systemic corticosteroids. Some patients may not meet the histopathological criteria for IgG sclerosing disease, yet still, show clinical improvement with glucocorticoids [14]. A dramatic clinical improvement was 
TABLE 1

\begin{tabular}{|c|c|c|c|c|c|c|}
\hline Case & Patient Age & Gender & $\begin{array}{c}\text { Clinical } \\
\text { presentation }\end{array}$ & $\begin{array}{c}\text { Presence of } \\
\text { extra-spinal } \\
\text { disease }\end{array}$ & Treatment & Outcome \\
\hline Chan et al. 2009 & 37 & Male & $\begin{array}{c}\text { Bilateral lower } \\
\text { extremity } \\
\text { weakness, } \\
\text { numbness, } \\
\text { unsteady gait } \times 2 \\
\text { weeks }\end{array}$ & Not reported & Not reported & Not reported \\
\hline Choi et al. 2010 & 46 & Female & $\begin{array}{c}\text { Progressive } \\
\text { bilateral lower } \\
\text { extremity } \\
\text { weakness and } \\
\text { numbness } \times 2 \\
\text { weeks }\end{array}$ & Not reported & Steroids & $\begin{array}{c}\text { Improved exam to } \\
\text { 'near normal' after } \\
\text { initial surgery; } \\
\text { progression } 2 \\
\text { months post op } \\
\text { required second } \\
\text { resection (subtotal) } \\
\text { with full recovery; } \\
\text { no recurrence at } 8 \\
\text { months }\end{array}$ \\
\hline $\begin{array}{l}\text { Lindstrom et al. } \\
2010\end{array}$ & 55 & Male & $\begin{array}{l}\text { Cord compression, } \\
\text { C3-C7 mass }\end{array}$ & Not reported & $\begin{array}{c}\text { Steroids; Radiation } \\
\text { Therapy } \\
\end{array}$ & $\begin{array}{l}\text { "Doing well" at } 15 \\
\text { month follow up }\end{array}$ \\
\hline $\begin{array}{l}\text { Lindstrom et al. } \\
2010\end{array}$ & 63 & Male & $\begin{array}{c}\text { Bilateral hand } \\
\text { numbness, C2-C3 } \\
\text { mass }\end{array}$ & Not reported & Not reported & Lost to follow-up \\
\hline Tajima et al. 2012 & 64 & Male & $\begin{array}{c}\text { Gradually } \\
\text { progressive and } \\
\text { worsening } \\
\text { dysphagia for } 1 \\
\text { month } \\
\end{array}$ & $\begin{array}{l}\text { Slight swelling in } \\
\text { both kidneys-renal }\end{array}$ & Steroids & $\begin{array}{l}\text { Improvement of } \\
\text { symptoms and } \\
\text { MRI findings at } 3 \\
\text { weeks }\end{array}$ \\
\hline Wallace et al. 2013 & 32 & Male & $\begin{array}{l}\text { Weakness of } \\
\text { dorsum of right } \\
\text { foot }\end{array}$ & Not reported & Not reported & Lost to follow-up \\
\hline Ezzeldin et al. 2014 & 55 & Male & $\begin{array}{c}\text { Diplegia of lower } \\
\text { extremities and } \\
\text { T4/T5 sensory } \\
\text { level for } 2 \text { weeks }\end{array}$ & Not reported & Steroids & $\begin{array}{c}\text { Able to ambulate at } \\
\text { discharge (timing } \\
\text { not specified) }\end{array}$ \\
\hline Kim et al. 2014 & 52 & Female & $\begin{array}{l}\text { Sudden weakness } \\
\text { of bilateral lower } \\
\text { extremities for } 2 \\
\text { days; paraplegia, } \\
\text { urinary retention }\end{array}$ & None & Steroids & $\begin{array}{c}\text { Unchanged after } 2 \\
\text { months }\end{array}$ \\
\hline Gu et al. 2016 & 43 & Male & $\begin{array}{c}\text { Neck pain for } 15 \\
\text { days, bilateral } \\
\text { lower extremity } \\
\text { numb- } \\
\text { ness/weakness, } \\
\text { bowel/bladder } \\
\text { dysfunction for } 4 \\
\text { days }\end{array}$ & $\begin{array}{l}\text { Patient declined } \\
\text { testing }\end{array}$ & Not reported & $\begin{array}{l}\text { Resolution of } \\
\text { symptoms at } 6 \\
\text { months post-op }\end{array}$ \\
\hline Radotra et al. 2016 & 50 & Male & $\begin{array}{c}\text { Progressive } \\
\text { bilateral lower } \\
\text { extremity } \\
\text { weakness for } 6 \\
\text { months }\end{array}$ & Not reported & Steroids & $\begin{array}{c}\text { Marginal } \\
\text { improvement in } \\
\text { strength } 7 \text { months } \\
\text { post-op }\end{array}$ \\
\hline Radotra et al. 2016 & 19 & Male & $\begin{array}{l}\text { back and left lower } \\
\text { extremity pain for } 1 \\
\text { year; subtle knee } \\
\text { extensor weakness } \\
\text { bilaterally }\end{array}$ & Not reported & Steroids & $\begin{array}{l}\text { Pain free at } 6 \\
\text { months; stable } \\
\text { exam }\end{array}$ \\
\hline
\end{tabular}


TABLE 1: Continued.

\begin{tabular}{|c|c|c|c|c|c|c|}
\hline Case & Patient Age & Gender & $\begin{array}{c}\text { Clinical } \\
\text { presentation }\end{array}$ & $\begin{array}{c}\text { Presence of } \\
\text { extra-spinal } \\
\text { disease }\end{array}$ & Treatment & Outcome \\
\hline Ferreira et al. 2016 & 57 & Female & $\begin{array}{l}\text { Worsening low } \\
\text { back pain for } 2.5 \\
\text { years; bilateral } \\
\text { lower extremity } \\
\text { numbness and } \\
\text { weakness }\end{array}$ & None & Steroids & $\begin{array}{c}\text { Recurrence and } \\
\text { progressive paresis } \\
\text { later improved } \\
\text { after third } \\
\text { resection and } \\
\text { long-term steroids }\end{array}$ \\
\hline Lu et al. 2016 & 55 & Male & $\begin{array}{c}\text { Diffuse numbness } \\
\text { and weakness for } 6 \\
\text { months; } \\
\text { constipation and } \\
\text { dysuria for } 7 \text { days }\end{array}$ & Not reported & $\begin{array}{c}\text { Steroids, } \\
\text { cyclophosphamide }\end{array}$ & $\begin{array}{c}\text { Recovered defeca- } \\
\text { tion/urination at } \\
20 \text { days; ambulated } \\
\text { independently at } 5 \\
\text { months } \\
\end{array}$ \\
\hline Rumalla et al. 2017 & 50 & Male & $\begin{array}{c}\text { Rapidly } \\
\text { progressive severe } \\
\text { back pain at T6 } \\
\text { level for } 3 \text { months; } \\
\text { acute onset } \\
\text { paraplegia, T6 } \\
\text { sensory level }\end{array}$ & $\begin{array}{l}\text { Right lung } \\
\text { associated with } \\
\text { adjacent vertebral } \\
\text { involvement }\end{array}$ & Steroids & $\begin{array}{l}\text { Near normal lower } \\
\text { extremity strength } \\
2 \text { months post-op }\end{array}$ \\
\hline Williams et al. 2017 & 46 & Female & $\begin{array}{l}\text { Worsening neck } \\
\text { pain and bilateral } \\
\text { upper extremity } \\
\text { paresthesias and } \\
\text { weakness for } 4 \\
\text { months } \\
\end{array}$ & Not reported & $\begin{array}{c}\text { Steroids, } \\
\text { azathioprine }\end{array}$ & $\begin{array}{c}\text { Improving strength } \\
\text { at } 6 \text { month post-op } \\
\text { visit }\end{array}$ \\
\hline Bridges et al. 2017 & 68 & Male & $\begin{array}{l}\text { Intermittent } \\
\text { thoracic spine pain } \\
\text { for } 3 \text { years, } \\
\text { progressive trunk } \\
\text { numbness and } \\
\text { bilateral lower } \\
\text { extremity } \\
\text { numbness for } 6 \\
\text { months, } \\
\text { dysequilibrium }\end{array}$ & None & Steroids & $\begin{array}{l}\text { Walking } \\
\text { independently with } \\
\text { resolution of pain } \\
\text { at } 3 \text { months } \\
\text { post-op }\end{array}$ \\
\hline Winkel et al. 2018 & 48 & Female & $\begin{array}{l}\text { Lower back pain, } \\
\text { neurogenic } \\
\text { claudication, right } \\
\text { lower extremity } \\
\text { radiculopathy, } \\
\text { extradural mass } \\
\text { L2-L3 level }\end{array}$ & None & Steroids & $\begin{array}{l}\text { Asymptomatic at } 1 \\
\text { year follow-up }\end{array}$ \\
\hline
\end{tabular}

achieved in our patient, particularly in her quadriparesis, after the administration of systemic corticosteroids. She was able to walk independently in just a few months. Her bowel and bladder dysfunction also recovered completely, but they took little longer, i.e. 6-9 months.

Currently, there is no consensus about the dose or duration of systemic corticosteroid therapy for IgG4-RD. Some physicians treat with systemic steroids temporarily for several months, while some patients in Japan get corticosteroids permanently [15]. We elected to keep our patient on lifelong steroids due to the severe symptoms at initial presentation, the significant disease morbidity, and the immediate elevation of IgG4 levels at the time that Dexamethasone was briefly held (Figure 3) [16, 17]. The life-long administration of corticosteroids in a pulsatile manner i.e. Dexamethasone $40 \mathrm{mg} /$ week in our patient has been shown similar outcomes, but with more acceptable side-effect profile [18]. Intermittent glucocorticoid administration at a high dose has a strong effect due to $100 \%$ saturation of cytosolic receptors; however, the effect would last only for a short period because receptor occupation rapidly reverts to the original value unless a new dose is given [18].

Therefore, a single high dose is unlikely to have sustained effect. Overall, the effects of corticosteroid pulses appear to include downregulation of activation of immune cells and proinflammatory cytokine production, leading to reduced expression of adhesion molecules and reduced movement of neutrophils into sites of inflammation. These effects are 


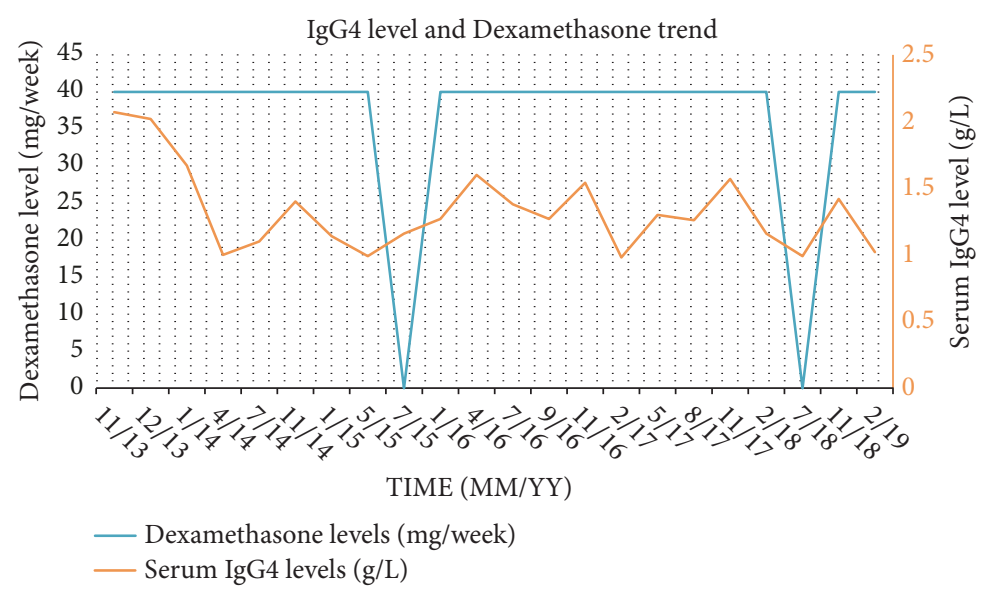

FIGURE 3: Double y-axis chart showing the IgG4 trends (orange line) and the Dexamethasone compliance (blue line) over time. Please note the immediate rise in serum IgG4 levels following the fall in Dexamethasone dosage.

qualitatively similar to those seen with anti-TNF-alpha therapy [19]. Corticosteroids are currently recommended orally for IgG4-RD according to the international consensus guidance [20]. Other routes of glucocorticoids administration, such as intrathecal and epidural routes of administration have risks of arachnoiditis, spinal cord injury, and spinal infection [17]. More recently, experiments in mice indicate that glucocorticoids may have a similar role in B lymphocytes $[16,21-24]$; nonetheless, physicians are currently challenged with the choice of which glucocorticoids to use, what dose, and for how long to use them.

\section{Conclusions}

Though extremely rare, spinal cord compression could be the initial presentation of IgG4-RD. The IgG4-RD disease process can be rapidly ameliorated with systemic corticosteroid use, even in the late stages of the disease. Early diagnosis of this rare IgG4-RD disease entity, extradural spinal cord compression, and early treatment with systemic corticosteroids can decrease the disease mortality and morbidity and improve patients' quality of life [25].

\section{Conflicts of Interest}

The authors declare that they have no conflicts of interest.

\section{References}

[1] M. Divatia, S. A. Kim, and J. Y. Ro, "IgG4-related sclerosing disease, an emerging entity: A review of a multi-system disease," Yonsei Medical Journal, vol. 53, no. 1, pp. 15-34, 2012.

[2] S.-K. Chan, W. Cheuk, K.-T. Chan, and J. K. C. Chan, "IgG4related sclerosing pachymeningitis: a previously unrecognized form of central nervous system involvement in IgG4-related sclerosing disease," The American Journal of Surgical Pathology, vol. 33, no. 8, pp. 1249-1252, 2009.

[3] S. Takeuchi, H. Osada, S. Seno, and H. Nawashiro, "IgG4-related intracranial hypertrophic pachymeningitis: A case report and review of the literature," Journal of Korean Neurosurgical Society, vol. 55, no. 5, pp. 300-302, 2014.

[4] Y. Sireesha, M. Uppin, S. Ganti et al., "A series of biopsyproven patients with immunoglobulin G4-related neurological disease," Annals of Indian Academy of Neurology, vol. 22, no. 1, pp. 73-78, 2019.

[5] B. Baptista, A. Casian, H. Gunawardena, D. D'Cruz, and C. M. Rice, "Neurological manifestations of IgG4-related disease," Current Treatment Options in Neurology, vol. 19, no. 4, p. 14, 2017.

[6] J. H. Stone, Y. Zen, and V. Deshpande, "IgG4-Related disease," The New England Journal of Medicine, vol. 366, no. 6, pp. 539$551,2012$.

[7] S. O. Nambiar and T. I. Oliver, IgG4 Related Disease (IgG4-RD), StatPearls Publishing, Treasure Island, FL, USA, 2018.

[8] A. Tanaka, M. Moriyama, H. Nakashima et al., "Th2 and regulatory immune reactions contribute to IgG4 production and the initiation of Mikulicz disease," Arthritis \& Rheumatology, vol. 64, no. 1, pp. 254-263, 2012.

[9] E. Della-Torre, M. Lanzillotta, and C. Doglioni, "Immunology of IgG4-related disease," Clinical \& Experimental Immunology, vol. 181, no. 2, pp. 191-206, 2015.

[10] T. Kamisawa, Y. Zen, S. Pillai, and J. H. Stone, "IgG4-related disease," The Lancet, vol. 385, no. 9976, Article ID 1460, pp. 1460-1471, 2015.

[11] K. J. Bridges, C. H. DeDeaux, and K. D. Than, "IgG4-related disease presenting as intradural extramedullary lesion: a case report and review of the literature," British Journal of Neurosurgery, pp. 1-7, 2017.

[12] S. H. Kim, Y. Kang, S. H. Oh, S. Paik, and J. S. Kim, "Paraplegia in a patient with IgG4-related sclerosing disease: A case report," Annals of Rehabilitation Medicine, vol. 38, no. 6, pp. 856-860, 2014.

[13] M. Winkel, C. Lawton, O. Sanusi, C. Horbinski, N. Dahdaleh, and Z. Smith, "Neuro-surgical considerations for treating IgG4related disease with rare spinal epidural compression," Surgical Neurology International, vol. 9, no. 1, p. 209, 2018.

[14] M. Ezzeldin, A. Shawagfeh, V. Schnadig, R. Smith, and X. Fang, "Spinal cord compression associated with a systemic IgG4 disease (P3.025)," Neurology, vol. 82, 10 Supplement, 2014.

[15] A. Ghazale, S. T. Chari, L. Zhang et al., "Immunoglobulin G4associated cholangitis: clinical profile and response to therapy," Gastroenterology, vol. 134, no. 3, pp. 706-715, 2008. 
[16] M. A. Pufall, "Glucocorticoids and cancer," Advances in Experimental Medicine and Biology, vol. 872, pp. 315-333, 2015.

[17] D. A. Nelson and W. M. Landau, "Intraspinal steroids: History, efficacy, accidentality, and controversy with review of United States Food and Drug Administration reports," Journal of Neurology, Neurosurgery \& Psychiatry, vol. 70, no. 4, pp. 433443, 2001.

[18] B. P. Schimmer and K. L. Parker, "Adrenocorticotropic hormones; adrenocortical steroids and their synthetic analogs; inhibitors of the synthesis and actions of adrenocortical hormones," in Goodman \& Gilmans The Pharmacological Basis of Therapeutics, L. L. Brunton, J. S. Lazo, and K. L. Parker, Eds., pp. 1587-1612, McGraw-Hill, New York, NY, USA, 11th edition, 2006.

[19] M. D. Smith, M. J. Ahern, P. J. Roberts-Thomson, and P. P. Youssef, "Similar effects of pulse corticosteroid and tumor necrosis factor alpha blockade in rheumatoid arthritis: comment on the article by Taylor et al," Arthritis \& Rheumatology, vol. 44, no. 1, pp. 245-246, 2001.

[20] A. Khosroshahi, Z. S. Wallace, J. L. Crowe et al., "International consensus guidance statement on the management and treatment of IgG4-related disease," Arthritis \& Rheumatology, vol. 67, no. 7, pp. 1688-1699, 2015.

[21] C. Ploner, S. Schmidt, E. Presul et al., "Glucocorticoid-induced apoptosis and glucocorticoid resistance in acute lymphoblastic leukemia," The Journal of Steroid Biochemistry and Molecular Biology, vol. 93, no. 2-5, pp. 153-160, 2005.

[22] A. L. Gruver-Yates, M. A. Quinn, and J. A. Cidlowski, "Analysis of glucocorticoid receptors and their apoptotic response to dexamethasone in male murine B cells during development," Endocrinology, vol. 155, no. 2, pp. 463-474, 2014.

[23] G. I. Lambrou, S. Vlahopoulos, C. Papathanasiou et al., "Prednisolone exerts late mitogenic and biphasic effects on resistant acute lymphoblastic leukemia cells: Relation to early gene expression," Leukemia Research, vol. 33, no. 12, pp. 1684-1695, 2009.

[24] L. Bonapace, B. C. Bornhauser, M. Schmitz et al., "Induction of autophagy-dependent necroptosis is required for childhood acute lymphoblastic leukemia cells to overcome glucocorticoid resistance," The Journal of Clinical Investigation, vol. 120, no. 4, pp. 1310-1323, 2010.

[25] M. Ezzeldin, A. Shawagfeh, V. Schnadig, R. G. Smith, and $\mathrm{X}$. Fang, "Hypertrophic spinal pachymeningitis: Idiopathic vs. IgG4-related," Journal of the Neurological Sciences, vol. 347, no. 1-2, pp. 398-400, 2014. 


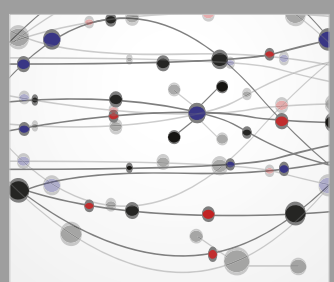

The Scientific World Journal
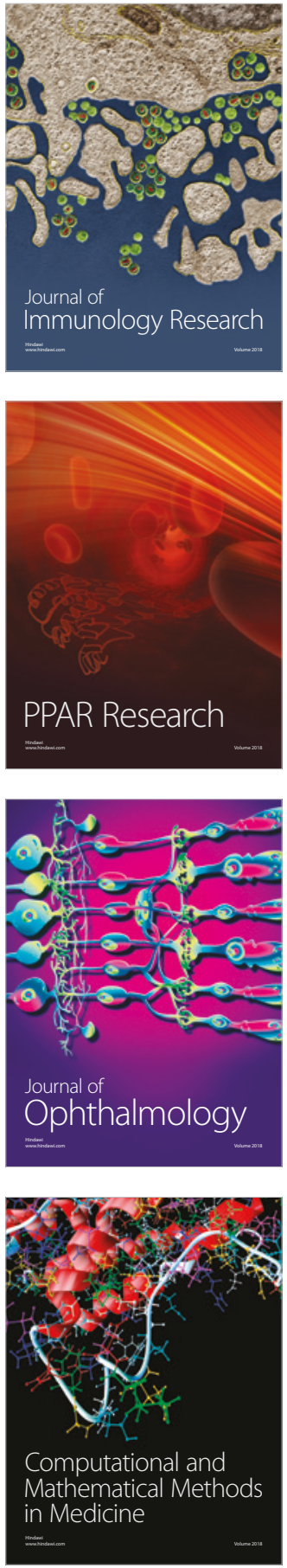

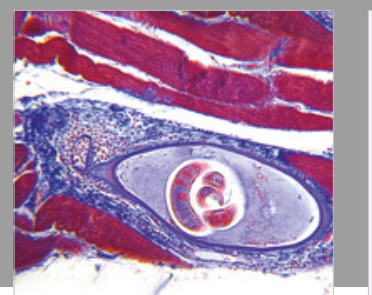

Gastroenterology Research and Practice

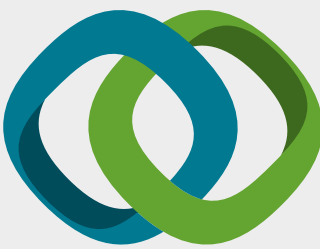

\section{Hindawi}

Submit your manuscripts at

www.hindawi.com
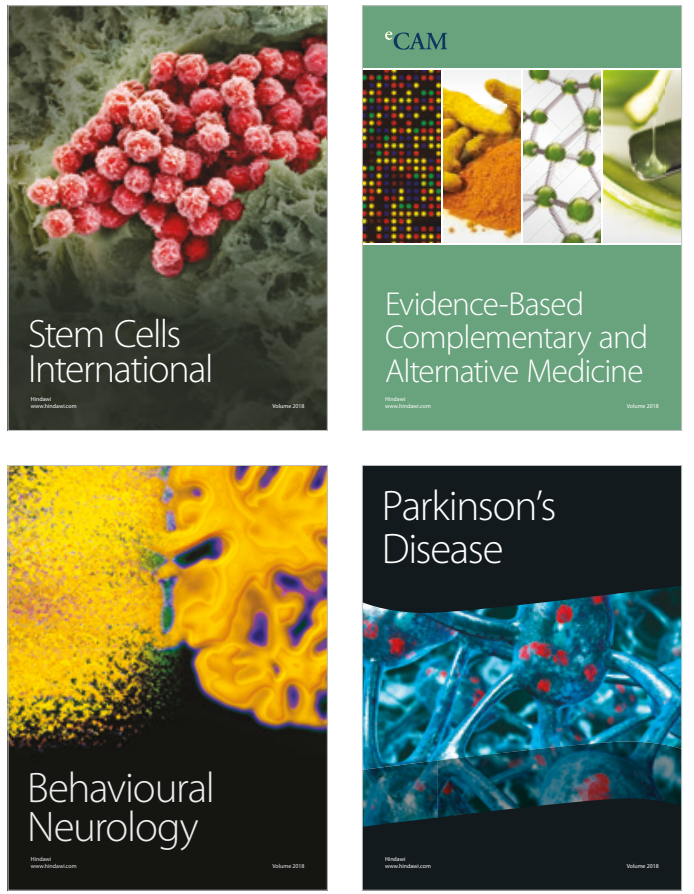

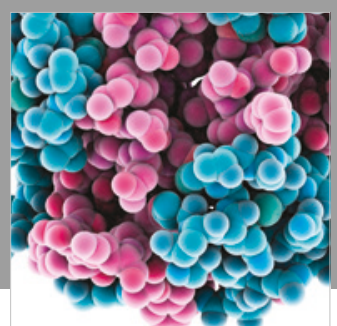

ournal of

Diabetes Research

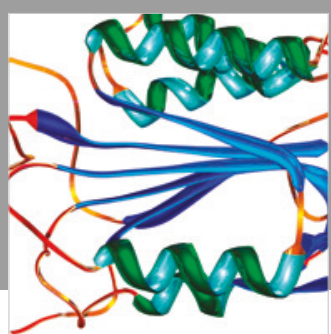

Disease Markers
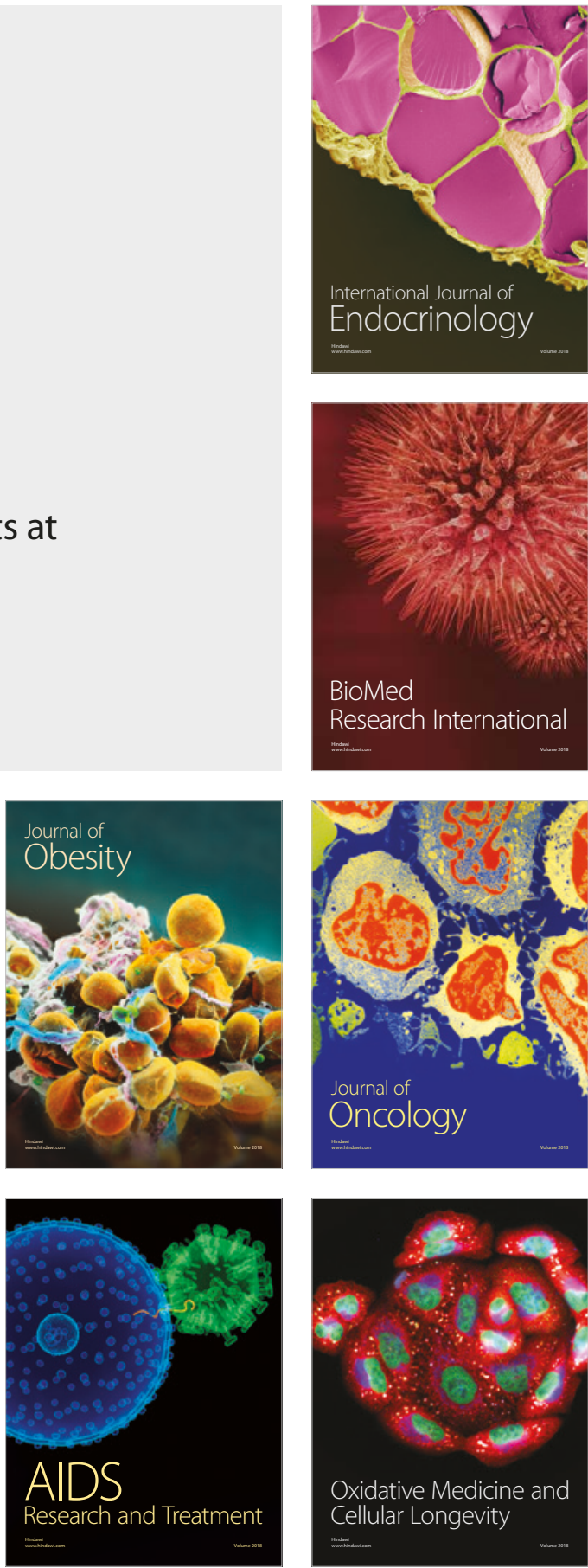